The Ancient Egyptian Sed-Festival and the Exemption from Corvee

Author(s): José M. Galán

Source: Journal of Near Eastern Studies, Vol. 59, No. 4 (Oct., 2000), pp. 255-264

Published by: The University of Chicago Press

Stable URL: http://www.jstor.org/stable/545782

Accessed: $31 / 05 / 2011$ 09:23

Your use of the JSTOR archive indicates your acceptance of JSTOR's Terms and Conditions of Use, available at http://www.jstor.org/page/info/about/policies/terms.jsp. JSTOR's Terms and Conditions of Use provides, in part, that unless you have obtained prior permission, you may not download an entire issue of a journal or multiple copies of articles, and you may use content in the JSTOR archive only for your personal, non-commercial use.

Please contact the publisher regarding any further use of this work. Publisher contact information may be obtained at http://www.jstor.org/action/showPublisher?publisherCode=ucpress.

Each copy of any part of a JSTOR transmission must contain the same copyright notice that appears on the screen or printed page of such transmission.

JSTOR is a not-for-profit service that helps scholars, researchers, and students discover, use, and build upon a wide range of content in a trusted digital archive. We use information technology and tools to increase productivity and facilitate new forms of scholarship. For more information about JSTOR, please contact support@jstor.org.

The University of Chicago Press is collaborating with JSTOR to digitize, preserve and extend access to Journal of Near Eastern Studies. 


\title{
THE ANCIENT EGYPTIAN SED-FESTIVAL AND THE EXEMPTION FROM CORVÉE
}

\author{
JOSÉ M. GALÁN, Consejo Superior de Investigaciones Científicas, Madrid
}

\begin{abstract}
A
MENHOTEP III's first sed-festival (ca. 1370 B.C.) is mentioned in a large number of dockets from Malqata as well as in the tombs of Kheruef and Khaemhet, the funerary temple of Amenhotep son of Hapu, the temple of Khonsu at Karnak, and in Soleb. In the temple of Soleb, among the various scenes in relief summarizing the ritual that was performed for the occasion, there is one scene that is accompanied by an inscription with a legal and administrative content. ${ }^{1}$ The text is arranged in columns, and the first one is placed just before a figure of a king sitting on a litter; he is wearing the Upper Egyptian crown and holding in his hand the flagellum and the heqa-scepter. The inscription is badly damaged, but some sections can still be read. The missing parts can be restored by referring to an inscription in Osorkon II's temple at Bubastis. ${ }^{2}$ The latter commemorates Osorkon's first sed-festival, celebrated in the twenty-second year of his reign (ca. 865 B.c.), in the fourth month of Akhet. Despite the geographical and chronological distance between the two inscriptions, there are only minor differences between them. ${ }^{3}$
\end{abstract}

Year 30, second month of Shemu. ${ }^{4}$ Appearing [in] Amun's temple, which is in the precinct of the sed-festival sitting on the southern litter ${ }^{5}$ and starting the protection $(h w)$ of the Two Lands, by the king. (Consisting of) the protection $(h w)$ of the musicians and singers ${ }^{6}$ of Amun and the protection ( $h w$ ) of every woman of [his town, ${ }^{7}$ who have been] dependents $(h m w t)$ since the times of the forefathers. They are in every household, taxed/levied ( $h t r)$ [with/for their work $(b 3 k)$ annually.

1 C. van Siclen III, "The Accession Date of Amenophis III and the Jubilee," JNES 32 (1973): 293, fig. 1. The drawing was made by N. de Garis Davies under the direction of J. H. Breasted. Other scenes of Amenhotep's sed-festival at Soleb can be found in $L D$, vol. 3, pls. 83-87.

2 E. Naville, The Festival-Hall of Osorkon III in the Great Temple of Bubastis (London, 1892), pl. 6; van Siclen, “Accession Date," pp. 295-98, fig. 2; W. Barta, "Die Sedfest-Darstellung Osorkons II. im Tempel von Bubastis," Studien zur altägyptischen Kultur 6 (1978): 25-42, pls. 1-6. A reconstructed version of Amenhotep III's inscription can be found in H. Goedicke, Problems concerning Amenhophis III (Baltimore, 1992), pp. 2834, fig. 2; K. A. Kitchen, The Third Intermediate Period in Egypt, 1100-650 B.C., 2d ed. (Warminster, 1986), pp. $320 \mathrm{f}$., also cites some inscribed blocks at Karnak in the so-called Bubastite room, mentioning a royal decree of Osorkon "to protect all the temples of Thebes."

[JNES 59 no. 4 (2000)]

(C) 2000 by The University of Chicago.

All rights reserved.

0022-2968/2000/5904-0002\$02.00.
${ }^{3}$ Even the scene that accompanies the text is very similar in both cases. The kings are being carried on a litter by a small group of attendants, and two staffs of millions of years are depicted before them. The texts, arranged in columns, are written in retrograde direction. Osorkon's command was issued at the end of the sed-festival ceremony, when he was returning to his palace.

${ }^{4}$ For other dated references and the duration of Amenhotep's sed-festival, see van Siclen, "Accession Date," pp. 290-96.

${ }^{5}$ Osorkon, on the contrary, is being carried on the northern litter $\left(s p^{3}\right)$, and he is wearing, accordingly, the Lower Egyptian crown.

${ }^{6}$ The terms are $h n r[w] t \check{s} m^{c} w$, but in Osorkon's inscription only hnit $(<h n r)$ is mentioned. A discussion of these terms can be found in S.-A. Naguib, Le clergé féminin d'Amon thébain, OLA 38 (Leuven, 1990), pp. 188-207, 235-39.

${ }^{7}$ I take niwty. $f$ as a nisba adjective, meaning "belonging to his town." Another reference to a god's town being protected $(h w t)$ by the king is mentioned in Hatshepsut's inscription at Speos Artemidos, Urk. IV 386, 13; see also A. H. Gardiner, "Davies's Copy of the Great 
Now his majesty is seeking a great deed of magnificence] for his father Amun-Re, as he proclaims the first sed-festival of his son, who is sitting on his throne, [and as he announces for him very many (sed-festivals) in Thebes, mistress of the Nine Bows. Thus, the king says in the presence] of his father Amun lord of the thrones of the Two Lands: "I shall protect $(h w)$ Thebes for you upon her height and [her width], being consecrated $\left(s w^{c} b\right)$ [once given to] her lord, without (any) interference [against her by the agents of the royal administration. ${ }^{8}$ Her people $(r m t)$ are protected $(h w)$ indefinitely] because of the great name [of the Good God]."

The king's words are in the form of a royal decree. The sed-festival provides the setting and the date. The reason for issuing it is introduced by a recurrent sentence in commemorative royal inscriptions: "now his majesty is seeking a great deed of magnificence. . . ." King and god based their relationship on reciprocal gestures, and the royal decree was presented as the compensation for the first sed-festival and Amun's announcement of more to come. Its content is generally understood as an exemption from corvée granted to Amun's cult personnel. It has to be stressed that the King's intention was not to benefit the people involved but exclusively to favor the god. The decree was not meant to reduce the fiscal burden of a certain group but to grant them the possibility to dedicate themselves exclusively to giving better service to the god.

The historicity of Amenhotep's gracious measure is confirmed by a second source. One of the statues of Amenhotep son of Hapu found at Karnak's Tenth Pylon has a text carved on a papyrus he holds over his crossed legs, as if the inscription were an original royal decree, one that would have probably been written in hieratic. ${ }^{9}$

Given by the grace of the king ${ }^{10}$ to the rapat, guard of the white chapel of Geb, ${ }^{11}$ the royal scribe and scribe of recruits, Amenhotep justified of voice, son of Hapu of Athribis, for the temple of Amun in Karnak. He (Amenhotep) says:

"I have acted as royal commissioner of his majesty, bringing in to him the people ( $r m t)$ of Thebes who were servants $(n-\underline{d} t)$ in the royal administration, in order to protect and consecrate $\left(h w w^{c} b\right)$ them forever for Amun lord of the thrones of the Two Lands, on (the occasion of ) the first sed-festival of his majesty.

Speos Artemidos Inscription," JEA 32 (1946): pl. 6 (19). Amenhotep's and Osorkon's texts mention only one place, Thebes. But if, on the other hand, niwty is taken as a dual and a second town is to be understood as being implicit in Osorkon's inscription, it would have been Tanis. Concerning Amun's cult in Tanis, see Kitchen, Third Intermediate Period, 2d ed., pp. 426-30. Van Siclen, "Accession Date," p. 297 (i), has suggested, however, Bubastis as the possible second town. Goedicke, Amenophis III, p. 31, has proposed that the dual might refer to the two parts of Thebes, the eastern and the western sides.

${ }^{8}$ On $r w d w$ "agents," see J.-M. Kruchten, "L'évolution de la gestion domaniale sous le Nouvel Empire égyptien," in E. Lipinski, ed., State and Temple Economy in the Ancient Near East, OLA 5-6 (Leuven, 1979), pp. 517-25. A discussion on pr-nsw can be found in D. Lorton, "What Was the $P R-N S W$ and Who Managed It? Aspects of the Royal Administration in 'The Duties of the Vizier'," SAK 18 (1991): 291-316.
9 CCG. 44862; M. G. Legrain, "Au pylône d'Harmhabi à Karnak (X' pylône)," ASAE 14 (1914): 19, 22-24; A. Varille, Inscriptions concernant l'architecte Amenhotep fils de Hapou, BdE 44 (Cairo, 1968), pp. 18-24; Urk. IV 1834,6-18. This passage is included in M. Valloggia, Recherche sur les 'messagers' (wpwtyw) dans les sources égyptiennes profanes (Geneva and Paris, 1976), p. 104 (no. 45); W. Helck, Der Einfluß der Militarführer in der 18. ägyptischen Dynastie (Hildesheim, 1964), pp. 8 f.; idem, Materialien zur Wirtschaftsgeschichte des Neuen Reiches, vol. 3 (Wiesbaden, 1963), p. 327.

${ }^{10}$ Varille, Amenhotep fils de Hapou, p. 9, explains and translates the opening formula as "(statue) donnée comme témoignage de faveur envers un familier du roi." The expression di $m$ hswt $n t h r-n s w$ is related to Amenhotep's statement that he had reached eighty years of age being "great of royal grace" ( $w r h s w h r-n s w), U r k$. IV 1828,$7 ; 1829,10$.

${ }^{11}$ See Helck, " $R p^{c} t$ auf dem Thron des $G b$," Or., n.s., 19 (1950): 416-34. 
After the king appointed me to (re)organize Amun's temple, I assigned the $w a b$-[priest]s in [their] places [...] in the [entire] land. The king [confirmed] me as master of ceremonies of every feast of Amun, and I met all his offerings daily."

According to an inscription in Kheruef's tomb, Amenhotep III performed ceremonies and rewarded officials at his first sed-festival following practices written in ancient documents. ${ }^{12}$ Was his royal decree also part of the same tradition? We have no evidence of it for earlier kings, ${ }^{13}$ but the possibility cannot be completely ruled out.

Osorkon's replication of Soleb's inscription has raised doubts about whether Osorkon really issued this decree or whether his craftsmen just made use of an old text. ${ }^{14} \mathrm{Be}$ that as it may, he was not the first one to reenact this policy. Around thirty years after Amenhotep's, a similar royal decision was made public and inscribed for the record by Tutankhamun. In his "restoration" stela the following passage can be read: ${ }^{15}$

His majesty l.p.h. consecrated $\left(s w^{c} b\right)$ the male and female dependents $(h m w h m w t),{ }^{16}$ singers and dancers who were servants $(h \underline{d} t y w)^{17}$ in the royal administration, whose work/products $(b 3 \mathrm{kw})$ were reckoned at the palace, at the [Treasury] of the lord of the Two Lands. I shall cause that they be protected and safeguarded ( $h w m k w$ ) for all the forefathers and gods, hoping that they (forefathers and gods) will be satisfied by doing what their kas wish, (namely) that they protect ( $h w$ ) Ta-mery.

Tutankhamun's policy was intended to benefit the temples of his forefathers and the gods in general. Amun must have been included among them, since the stela was placed in Karnak. ${ }^{18}$ The inscription, as indicated by its modern label "restoration," presents the king's actions as a policy intended to eliminate the chaos that had developed under his predecessors. ${ }^{19}$ Although this might have been Tutankhamun's perception of the political situation he inherited or, more likely, the perception of the power elite around him, it is indeed a topos: the newly crowned king was frequently described as facing chaos and eventually restoring order in his realm. This important aspect of Egypt's royal ideology might have been based, among many other factors, on the circumstance that a newly crowned king had to reenact (or annul) all royal decrees concerning prerogatives, appointments, and the like issued by his predecessor, since all agreements involving the king did not concern the institution (such as the monarchy or the government, as would usually happen today), but they were "signed"

12 Urk. IV 1867, 15-16.

${ }^{13}$ L. M. Berman, author of the chapter dedicated to "Amenhotep III and His Times" in A. P. Kozloff and B. M. Bryan, Egypt's Dazzling Sun: Amenhotep III and His World (Cleveland, 1992), states on p. 40: "Not since the Twelfth Dynasty (and perhaps not even then) was there a sed-festival on the scale of Amenhotep III's."

${ }^{14}$ Naville, The Festival-Hall of Osorkon II, p. 4; P. Vernus, "Inscriptions de la Troisième Période Intermédiare," BIFAO 75 (1975): 25 f.; Kitchen, Third Intermediate Period, $2 \mathrm{~d}$ ed., p. 321. A different opinion is helc $\rightarrow$ E. Uphill, "The Egyptian Sed-Festival Rites, JNES 24 (1965): 374.

${ }^{15}$ Urk. IV 2030, 611; Legrain, "Au pylône d'Harmhabi," pp. 23 f.; Varille, Amenhotep fils de Hapou, p. 22; J. Bennett, "The Restoration Inscription of Tut ${ }^{c}$ ankhamūn," JEA 25 (1939): 10; W. J. Murnane, Texts from the Amarna Period in Egypt (Atlanta, 1995), p. 214.
${ }^{16}$ Earlier, the inscription mentions that the newly crowned king had "filled the storehouses (of the temples) with male and female dependents ( $h m w$ hmwt) and with the products of his majesty's booty"; see Urk. IV $2029,13$.

17 Defective writing for $n$ - $d t$. This term and the two previous ones, $\breve{s} m^{c} w t$ and $h b y t$, have feminine determinatives.

${ }^{18}$ It was set up against the Third Pylon, which was the main entrance to the temple at that time. The royal policy, however, seems to have been conceived at Memphis, in the palace of Thutmosis I, as mentioned in the text; see Urk. IV 2028, 7; 2031, 15.

${ }^{19}$ In this context it is interesting to note the list of dues (htri) paid annually by a large number of temples from all over Egypt to the Aton sanctuaries at Karnak, recorded in talatats from Karnak's Ninth Pylon; Cl. Traunecker, "Données nouvelles sur le début du règne d'Aménophis IV et son œuvre à Karnak," JSSEA 14 (1984): 60-69. 
by the king's person/majesty. ${ }^{20}$ Thus, it should not seem odd if Amenhotep III's decree was reissued nearly literally by Tutankhamun or even if the former repeated, or better, continued a previous royal policy.

The limited validity of a legal document, which was connected to the life-span of the king who issued it, did not stand in opposition to the clause included in royal decrees that the king's decision was meant to extend beyond his reign, to be in force indefinitely. Indeed, with such a clause the king was expressing a wish, inviting his successors to uphold his decisions and compromises. ${ }^{21}$ In Amenhotep's and Osorkon's texts, officials of the royal administration were prevented from acting against the pharaoh's decisions. ${ }^{22}$ It has been debated whether or not the decree's validity, expressed by the adverbial clause hr hnty in Osorkon's text, refers to a limited period of time, perhaps even just to the year of the proclamation. ${ }^{23}$ In this connection, it should be noted that Amenhotep son of Hapu refers to the duration of Amenhotep III's decree as $r n h h$, "forever," and that similarly the royal decree concerning Amenhotep's funerary temple uses the adverbial construction $m$ - $h t n h h .{ }^{24}$

Tutankhamun's measures to benefit Egypt's temples were not proclaimed at his sedfestival (it seems he did not celebrate one), but they were presented as being related to his coronation. ${ }^{25}$ His munificence towards his father Amun was set in direct connection with his becoming a strong and efficient king. ${ }^{26}$ Assuming that the sed-festival is a sort of revival of the king's coronation in order to renew his power, as the ceremony is generally understood, ${ }^{27}$ it might be useful to search for possible parallels of the protective $(h w)$ measures taken by the kings at the time of their accession to the throne.

${ }^{20}$ See, for example, the biographical inscription of Khnumhotep II, where he summarizes how the first kings of Dynasty XII successively appointed members of his family to govern the province; P. E. Newberry, Beni Hasan, vol. 1 (London, 1893), pp. 58-63; pls. 25-26. See n. 37 below for more on this subject.

21 As pointed out, for example, in Apries's decree of year 13 (576 B.C.), "protecting and safeguarding" ( hw $m k t$ ) land, cattle, priests, and dependents attached to the temple of Ptah in an area near Memphis: 'My majesty has commanded the re[establishment of what has been done] by the ancestors in this temple of Ptah, so that what I have done would be reestablished by the [successor]s, for indefinite years"'; see P. der Manuelian, Living in the Past: Studies in Archaism of the Egyptian Twenty-Sixth Dynasty (London, 1994), pp. 373-80. The fact that these decrees were copied on stone, including the king's wish that his decision should be valid forever, in most cases, might have made the recarving of the same text by successive kings unnecessary (see the passage from Pepi II's decree translated below).

${ }^{22}$ The text reads: $n n \underline{d} 3-t 3$ r.s in $r w d w n$ pr-nsw. The same warning is attested in the royal decree appointing Nebamun as chief of police of two areas in western Thebes and granting ( $r d i t$ ) him all his belongings (Urk. IV 1619, 2-4) and again in the Nauri decree of Seti I, in a passage translated below. The expression $n n \underline{d} 3-t ?$ is also common in private legal documents. The usual way to indicate a prohibition, mentioned as one of the purposes of the Nauri decree, is $r$ tm rdit . . ; see Gardiner, "Some Reflections on the Nauri Decree," JEA 38 (1952): 28. Prohibitions against the action of officials are also part of Old Kingdom royal decrees, expressed by the formula $n \operatorname{rdi}(. n) h m(. i) \ldots$; see Goedicke, Königliche Dokumente aus dem Alten Reich, ÄA 14 (Wiesbaden, 1967), p. 235.

${ }^{23}$ See Kitchen, Third Intermediate Period, $2 \mathrm{~d}$ ed., p. 321, n. 433; Goedicke, Amenophis III, p. 33.

24 A royal decree was issued by Amenhotep III providing the funerary temple of Amenhotep son of Hapu with hmw and hmwt; see Varille, Amenhotep fils de Hapou, pp. 67-75.

${ }^{25}$ Murnane, Texts from the Amarna Period, p. 243, n. 19 , noted that the monument's date cannot be year 1 , as proposed by Helck in Urk. IV 2025, 18. Nevertheless, the inscription tries to relate the actions described in it to the moment "when his majesty appeared as king," Urk. IV 2027, 2; 2028, 2-3.

${ }_{26}$ Urk. IV 2028 7-11; 2031, 15-2032, 15.

27 K. Martin, "Sed-Fest," $L \ddot{A}$, vol. 5, cols. 782-90. C. J. Bleeker, Egyptian Festivals: Enactments of Religious Renewal (Leiden, 1967), pp. 111 f., expresses doubts about the connection between the sed-festival and the coronation, but he concentrates exclusively on the rituals. At the sed-festival, the king also made appointments and distributed rewards among his officials, as mentioned by Amenhotep son of Hapu (Urk. IV 1837, 7-15) in his mortuary temple:

[Year thirty], third month of Shemu, day two. The true royal scribe, his] beloved, [scribe of recruits], Amenhotep, was appointed administrator on the last day of the first sedfestival of his majesty, after he received adornments of gold and every precious and noble stone, and (after) the Hathornecklace (made) of electrum and every precious stone was placed at his neck. He sat down on the throne of gold in front of the dais, his limbs [dressed] with fine linen, the best linen $[\ldots]$. 
Horemheb's coronation inscription records that after the ceremony, Amun having returned to Thebes, he "set in order this land and established it according to Re's time," restoring temples, fashioning divine statues, establishing daily offerings, and assigning $w a b$-priests and lector-priests from the choice of his army to be in charge of fields and cattle from which the religious ceremonies would get supplies. ${ }^{28} \mathrm{He}$ does not seem to have issued any decree exempting Karnak's personnel from civil work, but he certainly showed favor to Amun's temple on the occasion. It should be noted that Amenhotep son of Hapu, in his brief account (translated above), brings together his role in the sed-festival and his (re)organization of Karnak's personnel. In the same vein, before mentioning the consecration of certain personnel for the gods' service, Tutankhamun's stela mentions how he appointed priests from among the children of the towns' chieftains, sons of well-known men, and how he filled the temples' storehouses with dependents $(h m w$ h $h m w t)$ and goods from his majesty's booty. ${ }^{29}$ It seems, therefore, that the exemption from corvée has to be understood in the context of a whole range of measures by which the king showed favor to one or more divine centers on special occasions during his reign.

Seti I issued a decree in his fourth regnal year (ca. 1300 B.C.), 1st month of Peret, day 1, described as "starting eternity, beginning happiness" ( $h 3 t n h h \breve{s} s p 3 w t-i b) .{ }^{30}$ At that time, he was in Memphis, and his declaration concerned "the temple of millions of years of the king of Egypt Men-maat-re, (whose) heart is satisfied in Abydos," possibly a reference to a subsidiary estate of the great temple of Osiris north of the Third Cataract (since the inscription was carved on a large rock at Nauri) or more likely a reference to Seti's temple at Abydos. ${ }^{31}$ The purpose was to protect and safeguard ( $h w y m k y)$ all its people ( $r m t)$, i.e., to consecrate $\left(s w^{c} b\right)$ the temple and to ensure its property and income. Everyone whose economic activity was connected to the temple would from then on perform their temple functions $(h n)$ exclusively and without any interference ( $n n$ rdit $\underline{d} 3 . t w t 3 r . s n) .{ }^{32}$ In fact, the viceroy of Kush or anyone who was merely sent on a mission to Kush was forbidden to disturb ${ }^{33}$ any of the temple's subjects there, men or women. Among the various cases cited as examples, the decree mentions several times that people were not to be seized "as captured, as transferred (from one district to another), as service workmen, as forced labor for ploughing, or as forced labor for reaping." 34

\footnotetext{
${ }^{28}$ Urk. IV 2119, 8-2120, 17. See Gardiner, "The Coronation of King Haremhab," JEA 39 (1952): 13-31.

${ }^{29}$ Urk. IV 2029,9-10,13. According to the Speos Artemidos inscription, Hatshepsut's protection ( $h w t)$ concerned mainly the restoration of temples and the renewal of cult services and offerings (see n. 7 above). A. Spalinger, in "Some Revisions of Temple Endowments in the New Kingdom," JARCE 28 (1991): 22-29, associates the protection and consecration of temples with their inspection (sip) by royal commissioners and the establishment of divine offerings ( $h t p w-n t \underline{t}$ ).

${ }^{30}$ KRI. I 45, 6-58, 15. In Speos Artemidos, it was $h \zeta t r n h \underline{h} \breve{s} s p \underline{d} t$, referring to his year 1 ; KRI. I 41,10 . This descriptive introduction might be related to the beginning of Seti I's nebty-name: whm mswt, "reborn," which seems to announce a political new era, especially when following a year-date, as in KRI. I 9, 3; see A. Niwinski, "Les périodes WHM MSWT dans l'histoire de l'Egypte: Un essai comparatif," Bulletin de la Société Française d'Égyptologie 136 (1996): 5-26. Horemheb's decree mentions in the preamble "the day [of] starting eternity and beginning [. . .]"; see Urk. IV 2141, 7. Co-
}

incidentally, a few lines below, it is stated that "Ta-mery has re-cycled" (whm.n.f $\breve{s} n w)$, and in the conclusion Horemheb announces "I shall be reborn (whm mswt) like the moon"; see Urk. IV 2142, 1; 2161, 6.

31 Kitchen, Ramesside Inscriptions Translated and Annotated: Notes and Comments, vol. 1 (Oxford, 1993), p. $53(\$ 96)$. Note that at the beginning of the text the Ennead addresses the king saying: "You shall cause Abydos to be protected again"; KRI. I 47, 2-3. Spalinger, "Temple Endowments," p. 35, relates the Nauri Decree with Seti's inauguration of his temple at Abydos.

${ }^{32}$ KRI. I 52, 9-13. The latter expression was also used in Amenhotep's and Osorkon's decrees. People's "protection" is mentioned also, for example, in KRI. I 50, 4-9; 52, 9-11; 58, 11-12.

33 A number of verbs are mentioned to indicate a transgression or abuse against someone attached to the temple. The most frequent one is $t h$ "to harm, afflict, disturb," but others are: $i \underline{t}$ ว " to seize," $t k n$ "to approach," $h d$ "to obstruct," and $s^{c}$ " to detain" (boats).

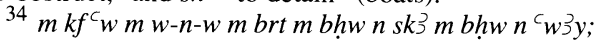
KRI. I 51, 5-8; 52, 13-16; 53, 1-6; 57, 8-10. On the 
Similar phraseology to that used in the Nauri decree can be seen in the Kanais inscription of year 9, through which Seti "protected and safeguarded" ( $h w w m k w$ ) the transport contingents for the gold-washers attached to the newly built temple there, whose task $(h n)$ was the delivery of gold to his temple, called "Men-maat-re." ${ }^{35}$ Kanais is explicitly said to be under the authority of the Abydos temple ( $\underline{h} r$ st- $\underline{h} r \underline{h} w t . i m \underline{\jmath} b \underline{d} w$ ). It seems Seti I had a special preference for the Osiris temple at Abydos, and in order to show favor to it he issued decrees similar to those of Amenhotep III at Soleb and Osorkon at Bubastis and also similar to Tutankhamun's and to the measures proclaimed by Horemheb at his coronation.

Royal decrees protecting $(h w)$ specific social groups, such as cult personnel or workmen attached to a temple, from complying with certain compulsory state labor obligations are known since the Old Kingdom. ${ }^{36}$ At least one of them, "Coptos A," is dated to the first sedfestival celebration of the reigning king, Pepi I. ${ }^{37}$ The decrees' general purpose is clearly expressed in two of them issued under Pepi II: ${ }^{38}$

A copy of this decree should be displayed, inscribed on a limestone stela at the doorgate of Min's temple in Coptos, in the Two Horus province, so that the officials of this province will see (it) and will not seize these hem-priests for any labor of the royal administration, for the length of eternity.

The idea of "protection" was expressed in Egyptian by various terms with slightly different uses, nuances, and connotations. The verb $h w$ was generally used to express the granting of a favor or privilege, a distinction that will benefit the recipient, a person or a territory. ${ }^{39}$ This nuance can clearly be seen in expressions such as "your father Amun has protected (hw) you with millions of sed-festivals"; 40 "may your father Amun protect $(h w)$ you with life, duration, and dominion." 41 Horemheb's decree was issued "to protect $(h w)$ the entire

term brt, see Kitchen, "Egypt, Ugarit, Qatna and Covenant," UF 11 (1979): 453-64, who translates it as "(hire-) contract," "hired labor paid at an agreed rate." The text, however, seems to point to various cases of forced requisition of people, and for that reason I would agree with J. E. Hoch, Semitic Words in Egyptian Texts of the New Kingdom and Third Intermediate Period (Princeton, 1994), pp. 108 f. (no. 135), who translates brt as "obligatory service." The meaning "corvée" is excluded for brt by Kitchen and by Gardiner, "Some Reflections on the Nauri Decree," pp. $28 \mathrm{f}$., since "corvée" is given for $b h w$, as in $W b$. I 468, 7-8; also followed by Helck, "Abgaben und Steuern," $L \ddot{A}$, vol. 1, col. 8; and "Frondienst," $L \ddot{A}$, vol. 2, cols. $333 \mathrm{f}$. There are several words that are translated as "corvée" only through the context; see, for example, Goedicke, Königliche Dokumente, pp. 26 f., 244 f.; C. J. Eyre, "Work and Organisation of Work in the Old Kingdom," in M. A. Powell, ed., Labor in the Ancient Near East (New Haven, 1987), pp. 18-20. As for the compound $w-n-w$, "(someone seized as) transferred (from one district to another)," it might have a parallel formulation in the Kanais inscription, where it is said: "as for anyone who shall disturb $(t h)$ any of them (gold-washers of the temple), who takes (them) to another place ..." (rdiw $r k t$ $s t), K R I$. I 69, 15. On this clause, and specifically on $m$ $k f^{\complement} w$, see W. F. Edgerton, "The Nauri Decree of Seti I: A Translation and Analysis of the Legal Portion," JNES
6 (1947): 227 f.; Gardiner, "Some Reflections on the Nauri Decree,” pp. 24-27.

${ }^{35}$ KRI. I 67, 13-70, 4 (text C).

36 Goedicke, Königliche Dokumente, pp. 244-47; Eyre, in Labor, pp. 18-20; I. Hafemann, "Zum Problem der staatlichen Arbeitspflicht im alten Ägypten I: Die königlichen Dekrete des Alten Reiches," Altorientalische Forschungen 12 (1985): 3-21.

${ }^{37}$ Urk. I 214, 9; Goedicke, Königliche Dokumente, pp. 41-54, fig. 4. For the date of the other decree, see pp. 12-14, especially the formula $r$ gs htm nswt $\underline{d} s . f$, "sealed at the side of the king himself," followed by the indication of the month and day.

${ }^{38}$ Urk. I 282, 9-14; 286, 1-6; Goedicke, Königliche Dokumente, p. 88 (x), fig. 8, and p. 118 (x), fig. 9. See also B. J. J. Haring, Divine Households: Administrative and Economic Aspects of the New Kingdom Royal Memorial Temples in Western Thebes (Leiden, 1997), p. 2.

39 To translate $h w$ as "to exempt," even in a legal context, is to convey the sense of the whole text based on one of its words, as pointed out by van Siclen, "Accession Dates," p. 297 (f), as opposed to Kitchen, Third Intermediate Period, 2d ed., p. 321, n. 429, and Goedicke, Amenophis III, p. 30, who interprets hw as "to exert royal authority over something, which in the case of taxation has the technical meaning of exemption."

${ }^{40}$ Urk. IV 2069, 13.

41 Ibid., 2038, 18; 2112, 14; 2169, 7. 
land," 42 "to regulate $(h n)$ the entire land." ${ }^{33}$ Thus, while the gods protect $(h w)$ the king, the latter protects the Two Lands, as a common royal epithet states ( $h w t 3 w y)$. In this vein, one epithet used by Amenhotep III was "(he) who protects the respectful one(s)" (hw sndm) ${ }^{44}$

The verb $h w$ is quite often accompanied by or placed parallel to the verb $m k,{ }^{45}$ here translated for convenience as "to safeguard." The latter has a more physical overtone, most of the time referring to the protection of a territory from external aggression; for instance, the king is identified with "Montu, great of khepesh-scimitar, who safeguards ( $m k)$ Egypt like Horus son of Isis," and he is described as one "who safeguards ( $m k)$ the land with his khepesh-scimitar." 46 A third verb, ndty, also has the meaning "to protect," but it is mostly used to describe a personal relationship, for example, to refer to how the king protects one or more gods or how a son protects his father. Amenhotep III is frequently called "protector of the one who is in Thebes" ( $n \underline{d} t y$ n imy $W 3 s t) .{ }^{47}$ In a certain way, the verb $n \underline{d} t y$ has a meaning similar to being "vigilant' $(r s)$ concerning someone else's affairs." 48

The act of "protecting" $(h w)$ is related to the act of "consecrating," $w^{c} b,{ }^{49}$ which has the positive and religious connotation of cleansing and purifying someone or something or, for example, a place. Concerning its legal use, there is a significant passage in the "Instruction Addressed to King Merikare," where the region of Memphis is described as having "ten thousand consecrated men ( $\left.n d s w^{c} b\right)$, who do not serve $(b 3 k w) . "{ }^{50}$ Amenhotep III's consecration of Thebes is related to the description of its new(?) status mentioned next, di.ti $n$ $n b . s$, "once given to her lord," which has not only an ideological/religious connotation, but also an administrative and fiscal one. Thebes is, consequently, honored by being set apart from the civil administration or from any fiscal obligation coming from the royal palace; from this point on, it will be liable exclusively to the temple administration.

The indirect beneficiaries of the measures taken by the king to commemorate his sed-festival are mentioned in several expressions referring to a group of dependents or subjects. In the Soleb temple, it is said that the royal decision concerned the women of Thebes who were hmwt.

42 Ibid., 2142, 15-16.

43 Ibid., $2161,17$.

44 Ibid., 1724, 10; M. Schade-Busch, Zur Königsideologie Amenofis III.: Analyse der Phraseologie historicher Texte der Voramarnazeit, HÄB 25 (Hildesheim, 1992), p. 334 (no. 305).

45 A. Théodoridès, "Dekret," $L \ddot{A}$, vol. 1, cols. $1037-$ 43. For Old Kingdom royal decrees, see Goedicke, Königliche Dokumente, p. 246. King Neferhotep (Dyn. XIII) reissued a decree protecting and safeguarding ( hwt mkt) the holy land south of Abydos for Wepwawet, forbidding the location of tombs in a certain area of the sacred precinct; A. Leahy, "A Protective Measure at Abydos in the Thirteenth Dynasty," JEA 75 (1989): 41-60. J. K. Hoffmeier, Sacred in the Vocabulary of Ancient Egypt, OBO 59 (Göttingen, 1985), pp. 138-40, relates the action of protecting an area in Neferhotep's decree with the qualification of the land as $\underline{d} s r$ "segregated," "sacred."

${ }^{46}$ Urk. IV 557, 3; 1693, 1-2;1700, 20. The action of safeguarding $(m k)$ land is associated with the king's strong arm or scimitar (hps) , or to his strength ( $p h t y)$, and it is related to his action of "pacifying" or "satisfying" (sgrh) the land, as already mentioned in the hymns of Sesostris III; K. Sethe, Aegyptische Lesestücke (Leipzig, 1924), pp. $66(17,22), 67(14)$. There seems to be also a close relationship between "protecting the Two Lands" and issuing "laws," as shown by Tutankhamun's "restoration" stela and Horemheb's decree. On $h p w$, see Lorton, "The Treatment of Criminals in Ancient Egypt through the New Kingdom," JESHO 20 (1977): 53-62; and "The King and the Law," Varia Aegyptiaca 2 (1986): 53-62, where he considers occurrences of $h p w$ referring to religious provisions. In this context, however, Lorton erroneously considers $h w t 3 w y$ as an "evidently political" expression, without any religious significance.

${ }^{47}$ Urk. IV 1688, 17; 1702, 14; 1703, 7; 1707, 4; 1857, 7; Schade-Busch, Königsideologie Amenofis III., p. 291 (no. $211 \mathrm{e}$ ).

${ }^{48}$ The term $s 3$ is generally used as a substantive, referring to the "protection" around $(h \zeta-t p)$ someone's body.

49 Helck, Wirtschaftsgeschichte des alten Ägypten im 3. und 2. Jahrtausend vor Chr. (Leiden and Cologne, 1975), p. 121. Spalinger, "Temple Endowments," pp. 22 f., n. 5, associates $h w i+m k i$ with $s w^{c} b$ and $s d s r$.

${ }^{50}$ Helck, Die Lehre für König Merikare (Wiesbaden, 1977), p. 61; J. F. Quack, Studien zur Lehre für Merikare (Wiesbaden, 1992), p. 187 (E 101; C II, 11). 
A few years later, a royal decree was issued providing the funerary temple of Amenhotep son of Hapu with $h m w$ and $h m w t$, who should work there for generations-forever-under the protection ( $n \underline{d} t t)$ of Amun. ${ }^{51}$ Amenhotep III's funerary temple had "its storehouses filled with $h m w$ and $h m w t$, with chieftains' children of every foreign land of his majesty's plunder." 52 Tutankhamun's "restoration" stela mentions that "he filled the storehouses (of the temples) with $h m w$ and $h m w t$ and with goods of his majesty's booty." ${ }^{\prime 3}$ Bakir pointed out that the $h m w$ were often foreigners, brought to Egypt through trade or as prisoners of war, and later on assigned by the king to temples or to prominent officials. ${ }^{54}$ The status of these people, however, is quite unspecific; therefore, $h m$ has been translated as "dependent." Perhaps in an attempt to be more specific, Amenhotep's and Osorkon's decrees immediately pointed out that the $h m w t$ mentioned were taxed/levied ( $h t r)$ annually for their work $(b 3 k) .{ }^{55}$ Horemheb's decree uses similar terminology. It singles out specific acts that the attendants of the offering storerooms of the pharaoh $\left(s d m-{ }^{\complement} \breve{s} n^{c} t n^{c} \zeta-p r w y\right)$, among others, were forbidden to carry out when enforcing the obligation ( $h$ tri) to comply with the service ( $p 3 b 3 k$ ) to the pharaoh by working or supplying products. Among these, the decree contemplates abuses in seizing someone's $p 3 \mathrm{hm}$ and/or $t 3 h m t$ to carry out compulsory work. ${ }^{56}$

Amenhotep son of Hapu simplifies the formulation of Amenhotep's decree and its terminology. He refers directly to people who were "servants" $(n-\underline{d} t)$. It seems as if the term $n$ - $\underline{d t}$, in a legal/social context, refers to a more precise situation of dependency than $h m$, probably to those who were compelled to work for or to contribute products to the royal administration once a year. According to Bakir, $n-\underline{d} t$ refers mostly to subjugated foreign countries and people who contribute service to benefit the god's institutions. ${ }^{57}$ Amenhotep son of Hapu mentions how he enlisted servants $(n-\underline{d} t)$ for the temples from among the prisoners of war captured by Amenhotep III. ${ }^{58}$ The term $n$ - $\underline{d} t$ is used to refer to foreign vassals of the Egyptian king who came (to him) with gifts on their backs. ${ }^{59}$

Tutankhamun's "restoration" stela mentions both $h m w / h m w t$ and $n-\underline{d} t$. The texts examined not only play with these two terms, but also refer to the musicians, singers, and dancers $\left(h n r, \breve{s} m^{c}, h b\right)$ attached to a temple. These occupations were usually carried out by more or less well-off women and men. ${ }^{60}$ The combination of the terms on Tutankhamun's "restoration" stela that refer to divergent social status is not contradictory but seems to be

51 Varille, Amenhotep fils de Hapou, pp. 67-85. The stela is dated to Dynasty XXI, but it is to be taken as a later version of an actual Amenhotep III decree.

52 Urk. IV 1649, 8-13.

53 Ibid., 2029, 13.

54 A. M. Bakir, Slavery in Pharaonic Egypt, SASAE 18 (Cairo, 1952), pp. 30-32.

55 Haring, Divine Households, p. 18; on htr to indicate "dues," "required payments," "obligations," see J. J. Janssen, Commodity Prices from the Ramessid Period: An Economic Study of the Village of Necropolis Workmen at Thebes (Leiden, 1975), pp. 456 ff.; Spalinger, "From Local to Global: The Extension of an Egyptian Bureaucratic Term to the Empire," SAK 23 (1996): 353-59; and on $b 3 k(w)$ to indicate "work," "produce," see Lorton, The Juridical Terminology of International Relations in Egyptian Texts through Dyn. XVIII (Baltimore, 1974), pp. 90 ff.; E. Bleiberg, "The Redistributive Economy in New Kingdom Egypt: An Examination of
B 3kw(t)," JARCE 25 (1988): 157-68; Janssen, “ $B 3 k w$ : From Work to Product," SAK 20 (1993): 81-94.

56 Urk. IV 2143, 15-2152, 15. See Kruchten, Le décret d'Horemheb (Brussels, 1981), pp. 64-68, 77-79, $206 \mathrm{f}$.

${ }^{57}$ Bakir, Slavery, p. 38; Lorton, Juridical Terminology of International Relations, pp. $115 \mathrm{f}$. A third term also frequently used to refer to foreign captives brought to Egypt and assigned to the temples' workshops, granaries, and fields is $m r t$; see Bakir, Slavery, pp. $22 \mathrm{f}$; Helck, Materialien zur Wirtschaftsgeschichte, pp. 321 ff.; and especially the following passages: Urk. IV 742, $12-743,1 ; 1147,7-11 ; 1442,3-15$, where the term is associated with work/produce $(b 3 \mathrm{kw})$ and the annual taxation $(h t r)$ for the temple. For a general description of temple personnel, see Eyre, in Labor, pp. 188 f., $204 \mathrm{f}$.

${ }^{58}$ Urk. IV 1821, 6; 1823, 19.

59 Ibid., 1920, 18-20.

${ }^{60}$ See n. 6 above. 
a way to generalize by citing representative individuals. In Old Kingdom decrees, both priests $(h m-n \underline{t} r)$ and dependents $(m r)$ were mentioned together as exempted from doing compulsory work for the royal administration. ${ }^{61}$ In Amenhotep's and Osorkon's decrees, the broad social scope touched on by the legal stipulations is explicitly covered by the use of the term rmt, "people," and by referring to all of Thebes as the area in question. Just why the texts focus on female temple personnel is difficult to ascertain. One can suggest that it may only reflect the increasing importance that Amun's female priesthood attained during the New Kingdom.

It must be remembered that the exemption from corvée, releasing certain people from the obligations of public service, was decreed for the temple's advantage, and not for the benefit of the people themselves. The group affected would from then on work for or give their wages exclusively to the temple. Thus, it was not a social measure but one solety concerned with the organization of the public economy, which included religious and lay institutions. ${ }^{62}$ From a political point of view, this kind of measure does not have to be seen as a loss of power by the crown or as a reflection of the increasing influence of the priestly "lobby" but as a redefinition of responsibilities within the same governmental structure. ${ }^{63}$

The royal decrees discussed in this article were issued to announce an exceptional measure taken as opposed to the usual custom or tradition. Their aim was to "protect" a group of people or a place from a government routine, to set them apart from the royal administration's policy of seizing people for corvée work. Through such decrees, the king ruled against the norm, and in fact there are negative formulations in this connection: "in order to prevent ...," expressing the decree's purpose; "his majesty does not allow . ..," introducing the decree's specifications $;{ }^{64}$ or the imperative "beware of," $(s 3 w)$ as in the Kanais inscription. Accordingly, the texts include the punishment (ir.tw hpw r.f) of a person who disobeys the royal command. ${ }^{65}$

Royal decrees list several hypothetical cases in which someone acts against what has been decreed, the protasis introduced by $i r+$ noun + nty ("as for any X who . . "). These cases

61 Urk. I 170-72; Goedicke, Königliche Dokumente, pp. 22-36, 211 f. (15); Hafemann, "Zum Problem der staatlichen Arbeitspflicht," pp. 5, $18 \mathrm{f}$.

62 Janssen, "The Role of the Temple in the Egyptian Economy during the New Kingdom," in Lipinski, State and Temple Economy, pp. 509-15. Note, for instance, that Thutmosis III gave to Amun as a gift three citystates, after his victory over Megiddo (Urk. IV 744, 3-8). They formerly belonged to the chief of Megiddo (Urk. IV 664, 17-665, 4), but from now on they would have to pay annual service ( $h$ tr $m b 3 k$ ) to the estate temple of Amun. The rest of Megiddo's territories were divided into plots and registered by the agents of the royal administration (Urk. IV 667, 10-12).

${ }^{63}$ Haring, Divine Households, pp. 17-20. Against this view, see Goedicke, "Cult-Temple and 'State' during the Old Kingdom in Egypt," in Lipinski, State and Temple Economy, pp. 128-31. Spalinger, "Temple Endowments," p. 1, argues that these kinds of decrees point out the king's ability to redirect the resources of the land.

${ }^{64}$ See n. 22 above.

65 Lorton, "Criminals in Ancient Egypt," pp. 2-64. While the Nauri decree specifies the number of blows, open wounds, and other punishments for each different transgression, the Kanais inscription threatens the transgressor by appealing to divine justice. Horemheb's decree is quite different from the rest, since it explicitly addresses "cases of greed" (spw $\left.n^{`} w n\right)$, Urk. IV 2161, 18. Its purpose was not to benefit a temple but to enhance the king's role as suppressor of evil and rescuer of order. The (re)establishment of order concerned different aspects of kingship: the appointment of officials (see n. 20 above), the renewal of vassal treaties, the subjugation of rebellious lands, the maintenance of temples and divine offerings, and so on. It was this last aspect that was usually chosen to portray the king as supporter of order, as in Tutankhamun's "restoration" stela. Why Horemheb chose a legal extract to "celebrate" order remains unclear.

${ }^{66}$ For a different interpretation, $\rightarrow$ Edgerton, "The Government and the Governed in the Egyptian Empire," JNES 6 (1947): 157; idem, "The Nauri Decree of Seti I: A Translation and Analysis of the Legal Portion," JNES 6 (1947): 227-30. He argues that "the Foundation's workmen were certainly not exempted from all forms of forced labor for the Nubian government. That purpose could have been accomplished by one short and 
try to illustrate what has until then been common practice. ${ }^{66}$ The positive formulation, that is, what is actually decreed, is occasionally introduced by $w p w$ - hr, "but instead . .," "on the contrary ...," $" 67$ and reflects the exceptional character of the stipulation, the break with the conventional. Since the decree was an exception to the norm, it was important to have it carved in stone and displayed in a pertinent public place, as stated in Pepi II's decree translated above (p. 260).

Thus, royal decrees issued to benefit religious institutions by exempting them from the obligations and demands of the various levels of the civil administration were the exception. They were favors granted to the god(s), through which certain people might attain a more comfortable life. This privilege implied the segregation of the temple properties, staff, and workmen, but the local character of the policy does not seem to have had major consequences in the overall administration of the country. The exemption from corvée seems to have been an appendix to the king's donation of gifts, land, and other resources to the temples, which he would grant on special occasions such as his coronation or the sed-festival.

simple sentence. The elaborate specifications discussed above prove the nonexistence of any such sweeping exemption" (p. 228). Gardiner, "Some Reflections on the
Nauri Decree," p. 26, responded: "the writer puts down just such potential offenders as come to his head."

${ }^{67}$ KRI. I 52, 9-10; 69, 12-13; 70, 1-2. 